\title{
Differentiation strategies for defence supply chain design
}

Thomas Ekström

Department of Military Studies, Swedish Defence University, Stockholm, Sweden

Per Hilletofth

Department of Industrial Engineering and Management, University of Gävle, Gävle, Sweden and Department of Industrial Engineering and Management, Jönköping University, Jönköping, Sweden, and

\author{
Per Skoglund
}

Department of Military Studies, Swedish Defence University, Stockholm, Sweden

\begin{abstract}
Purpose - Defence supply chains (SCs) aim at operational outcomes, and armed forces depend on them to provide availability and preparedness in peace and sustainability in war. Previous research has focussed on strategies for SCs aiming at financial outcomes. This raises the question of how suitable commercial supply chain strategies (SCSs) are for supply chain design (SCD) in defence. The purpose of this paper is to explain the constructs of SCSs that satisfy military operational requirements and to propose SCSs that are appropriate in defence.

Design/methodology/approach - This paper reports on a Delphi study with 20 experts from Swedish defence authorities. Through three Delphi rounds, two workshops and a validation round, these experts contributed to the reported findings.

Findings - The findings demonstrate that commercial SC constructs are acceptable and applicable in defence but not sufficient. An additional strategy is required to satisfy requirements on availability, preparedness and sustainability. The paper shows that different requirements in peace and war make it challenging to design suitable defence SCs and proposes eight SCSs that satisfy these requirements.

Research limitations/implications - The results emanate from the Swedish defence context and further research is required for generalisation.

Originality/value - This paper extends theory by investigating SCs aiming at operational outcomes. For managers in companies and defence authorities, it explicates how the unique issues in defence must influence $\mathrm{SCD}$ to satisfy operational requirements.
\end{abstract}

Keywords Delphi study, Supply chain strategies, Defence supply chain design, Military logistics

Paper type Research paper

(C) Thomas Ekström, Per Hilletofth and Per Skoglund. Published in Journal of Defense Analytics and Logistics. Published by Emerald Publishing Limited. This article is published under the Creative Commons Attribution (CC BY 4.0) licence. Anyone may reproduce, distribute, translate and create derivative works of this article (for both commercial and non-commercial purposes), subject to full attribution to the original publication and authors. The full terms of this licence maybe seen at http:// creativecommons.org/licences/by/4.0/legalcode

FMV and the Swedish Armed Forces (SwAF) funded this research but had no role in study design, data collection, analysis or interpretation, writing the article or in the decision to submit it for publication. The authors gratefully acknowledge the invaluable participation of the panellists and workshop participants. They participated as individuals and not as representatives of their employers. The authors would like to thank the two anonymous reviewers for their comments and suggestions, which have improved the paper significantly.

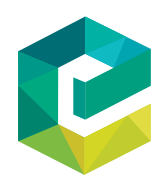

Received 23 June 2020 Revised 24 September 2020 Accepted 15 October 2020

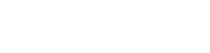




\section{JDAL 4,2}

\section{Introduction}

Supply chains (SCs) are becoming increasingly complex (Purvis et al., 2016), leaner, longer and more vulnerable (Christopher and Peck, 2004). Enhanced efficiency increases vulnerability to demand variability and disruptions (Purvis et al., 2016), which endanger operations and deliveries (Jüttner et al., 2003). Vulnerability to demand variability has prompted research on responsive SCs (Gunasekaran et al., 2008), whereas vulnerability to disruptions instigated research in SC resilience (Christopher and Peck, 2004). Melnyk et al. (2010) suggest that future SCs must deliver varying degrees of cost-related benefit, responsiveness, security, sustainability, resilience and innovation, depending on customers' requirements. Customers determine the success or failure of SCs (Mason-Jones et al., 2000a), and companies may have to sacrifice efficiency to satisfy requirements (Basnet and Seuring, 2016). However, how military customers' operational requirements should be satisfied in defence $\mathrm{SC}$ design $(\mathrm{SCD})$ has not been sufficiently researched (Yoho et al., 2013).

Efficiency is the default goal of SCD in the private sector (Basnet and Seuring, 2016), but the public sector is not profit-maximising (Wilhite et al., 2013). Defence authorities such as armed forces, defence procurement agencies and defence logistics organisations generate, use or support military forces. Military logistics supports armed forces to achieve operational outcomes, not financial outcomes (Yoho et al., 2013). Operational outcomes present unique SCD issues, which companies must consider (Melnyk et al., 2014). Furthermore, in military logistics, catastrophic events are not disruptions, they are its raison d'être (Martel et al., 2013). Military logistics must support force generation in peace and sustain operations in war (Davids et al., 2013). In such operations, "the first mile" is similar to business logistics, whereas the "last mile" is not, as the enemy may damage infrastructure and attack the SC (Glas et al., 2013). Leanness and efficiency are important requirements on defence SCs in peace, but the overarching requirements in war are agility and effectiveness (Kovács and Tatham, 2009). If companies want to match military customers' unique requirements, they must design defence SCs to serve two modes: peace and war. Defence SCs must be able to work in both modes at different times but must also be able to switch rapidly between them (Sharma and Kulkarni, 2016), through activation and mobilisation. The question is which implications these unique SCD issues have for the formulation of SC strategies (SCSs) in defence.

An SCS is a response to external contingencies, such as demand variability/uncertainty, product variety, desired customer lead-time and supply uncertainty/risk (Basnet and Seuring, 2016). It is a set of prioritised competitive priorities (Schnetzler et al., 2007), commonly including cost, quality, flexibility, innovation, speed, time and dependability (Chen and Paulraj, 2004). SCs must service a wide range of products and markets, and a recurrent caution is that "one size does not fit all" (Lee, 2002; Lovell et al., 2005; Christopher et al., 2006). SCSs must match the specific requirements of a product or a market (Fisher, 1997; Christopher et al., 2006; Melnyk et al., 2014) and customers' requirements (Godsell et al., 2006). Researchers have proposed SCS typologies, such as efficient/responsive (Fisher, 1997), postponement/speculation (Pagh and Cooper, 1998) and lean/agile (Naylor et al., 1999), which others have criticised for being too simplistic (Godsell et al., 2006; Hilletofth, 2012; Basnet and Seuring, 2016). In another stream of research, authors such as Sharman (1984) and Yang et al. (2004) have suggested SCS continuums, using the customer-order decoupling point (CODP) position as a demarcation between different SCSs. Customised SCD in defence presupposes the inclusion of military endusers' requirements. So, which are these requirements, and what is the military perspective on commercial SCD constructs, such as external contingencies, competitive priorities and SCSs?

Researchers have investigated appropriate SCSs in different industries, such as aerospace, fashion, automotive, chemicals, electronics, food, furniture, health care, home appliances, paper and steel (Nag et al., 2014) but not in defence. Functioning SCs are required 
to support nations' defence and security. Considering that the total military expenditure in the world is estimated to US\$1.8tn in 2018 (SIPRI, 2019), corresponding to 2.1\% of the total gross domestic product, research on defence SCSs is warranted. Indeed, Melnyk et al. (2014) call for more research to identify the unique SCD issues in military/defence. Furthermore, Yoho et al. (2013) encourage more research in defence SC resiliency and management.

This paper bridges the gaps in the literature regarding defence SCD. The purpose is to explain the constructs of SCSs that satisfy military operational requirements and to propose SCSs that are appropriate in defence. To formulate suitable SCSs, the study must establish the operational requirements, or unique defence SCD issues, and determine if commercial SCD constructs are acceptable, applicable and sufficient in defence. This paper operationalises the purpose through the following research questions:

$R Q 1$. How acceptable, applicable and sufficient are commercial SCD constructs in defence?

RQ2. Which SCSs satisfy defence authorities' operational requirements?

Based on a Delphi study, this paper extends SC management (SCM) and military logistics theory and military logistics practise, as follows. Firstly, it investigates the acceptability, applicability and sufficiency of commercial SCD constructs in Swedish defence. Secondly, it examines unique defence SCD issues and proposes SCSs that will satisfy them. Thirdly, it provides defence authorities with instruments to formulate and convey requirements to industry.

The paper is organised as follows. Section 2 reviews the related literature on military logistics and SCSs. Section 3 presents the methodology. Next, Sections 4 and 5 present and discuss the findings. Finally, Section 6 explicates theoretical contributions, practical implications and limitations and proposes further research.

\section{Literature review}

\subsection{Military logistics}

The operational purpose of military logistics is to ensure that the elements of military capability come together at the right place and time and in the right configuration (Swartz and Johnson, 2004). Military capability is the ability to achieve a specified objective, which can be to win a war. It depends on force structure, modernisation, readiness and sustainability, where the two latter reflect how quickly and for how long military forces are usable (Moore et al., 1991). Consequently, in military logistics, sustainability has a rather different meaning than in business logistics. The supply dimension of military logistics involves procuring, storing and distributing supplies to bridge the discrepancy between production and consumption (Hauk, 1964) or to ensure readiness and sustainability. Readiness consists of operational readiness, "ready for when", and mobilisation readiness, "ready for what" (Betts, 1995, p. 216), otherwise known as availability and preparedness. Availability and preparedness are military units' abilities to be committed to an activity without forewarning or after mobilisation. Sustainability is the ability to maintain the necessary level of combat power for the duration required to achieve objectives.

Compared to business logistics, military logistics faces a number of particular challenges. Whereas an error in business logistics can lead to a loss of profit, in military logistics, it can result in death or injury (Yoho et al., 2013). Furthermore, military logistics operates at three different levels of activity: peace, mobilisation and war (McGinnis, 1992). The logistics support for a country's armed forces is frequently required to operate in costefficient mode during peace but must be prepared to transition into war, in which effectiveness is paramount (Kovács and Tatham, 2009). Consequently, there is a dual 
JDAL 4,2

premise in defence SCD. In peace, defence SCs must satisfy requirements on availability and preparedness. In war, they must satisfy requirements on sustainability.

\subsection{Supply chain strategies}

An SC consists of all activities that manufacturers and distributors perform to create value, including purchasing, manufacturing and distribution (Chen and Paulraj, 2004; Hilletofth,

priorities, such as quality, flexibility, innovation, speed, time and dependability (Chen and Paulraj, 2004). Researchers have divided SCSs into efficient and responsive, which many equate with lean and agile (Selldin and Olhager, 2007; Basnet and Seuring, 2016). Companies that select low-cost, high quality and/or short delivery time as its competitive priorities should select a lean SCS, whereas with a focus on flexibility, an agile SCS is the best choice (Qi et al., 2017).

SCs perform physical and market mediation functions, where the physical mediation involves production, storage and distribution and market mediation matches supply with demand (Fisher, 1997; Aitken et al., 2005). Successful companies have realised that the right SCS is dependent on customer-orientation and on demand and supply variability (Lee, 2002). SCSs must be context-specific (Melnyk et al., 2014) and develop the optimum solution for a particularly competitive environment (Godsell et al., 2006). A differentiated SCS is one way that companies can be responsive to variable demand and maintain SC efficiency, and researchers have proposed several typologies to assist companies in selecting a suitable SCS (Hilletofth, 2009). Most typologies, exemplified in Table 1, are two-by-two matrices, with different dimensions and values. They determine segmentation by product-related, customer-related, supply-related or geography-related factors (MacCarthy et al., 2016). These typologies have in common that they present a discrete choice of one suitable SCS, in a set of two or four. At least one SCS emphasises efficiency/leanness, whereas the others are market mediation SCSs (von Falkenhausen et al., 2019). In another stream of research, scholars such as Yang et al. (2004) use postponement and CODP-positioning to construct strategy continuums. These continuums have in common that they use constructs from the typologies to propose market mediation strategies after the CODP (von Falkenhausen et al., 2019) and allow customised SC solutions, dependent on a unique situation. This paper distinguishes between these two waves of contributions as strategy typologies and continuums.

2.2.1 Strategy typologies. Fisher (1997) took segmentation and differentiation into SCM and asserted that mismatches between products and SCs are the causes of problems afflicting SCs. As a remedy, Fisher introduced innovative and functional products, requiring responsive and efficient $\mathrm{SCs}$, and produced a typology that has become a cornerstone in SCD (Perez-Franco et al., 2016). Since Fisher's seminal contribution, authors have proposed extensions and modifications. Lee (2002) expands Fisher's model with supply uncertainties and proposes two additional SCSs, risk-hedging and agile. Introducing value density and throughput, Lovell et al. (2005) propose a generic framework, including centralised and decentralised storage. Naylor et al. (1999) introduce leanness and agility from manufacturing into SCD. Building on these ideas, Mason-Jones et al. (2000b) and Aitken et al. (2005) introduce competitive priorities, and the concepts of market-qualifiers and order-winners. Roh et al. (2014) update these contributions and add innovative features as an order-winning criterion. In a series of contributions, Christopher (2000), Christopher et al. (2006) and Christopher et al. (2009) explore the combination of leanness and agility with external contingencies, for example, duration of life cycle, delivery lead-time, volume, product variety and variability in demand, supply or process. Based on production-to-delivery-ratio and 


\begin{tabular}{|c|c|c|c|c|}
\hline $\begin{array}{l}\text { Author(s) } \\
\text { (Year) }\end{array}$ & Dimensions & Values & Segments/Strategies/Competitive priorities & $\begin{array}{l}\text { Defence } \\
\text { supply chain }\end{array}$ \\
\hline \multirow[t]{2}{*}{ Fisher (1997) } & Product & $\begin{array}{l}\text { Functional, } \\
\text { Innovative }\end{array}$ & \multirow[t]{2}{*}{ Mismatch*, Match*, Match*, Mismatch* } & \\
\hline & Supply chain & $\begin{array}{l}\text { Responsive, } \\
\text { Efficient }\end{array}$ & & \\
\hline \multirow[t]{2}{*}{$\begin{array}{l}\text { Pagh and } \\
\text { Cooper (1998) }\end{array}$} & & $\begin{array}{l}\text { Speculation, } \\
\text { Postponement }\end{array}$ & \multirow{2}{*}{$\begin{array}{l}\text { Manufacturing postponement**, Full } \\
\text { postponement**, Full speculation**, Logistics } \\
\text { postponement** }\end{array}$} & 187 \\
\hline & Manufacturing & $\begin{array}{l}\text { Postponement, } \\
\text { Speculation }\end{array}$ & & \\
\hline \multirow[t]{2}{*}{$\begin{array}{l}\text { Naylor et al. } \\
\text { (1999) }\end{array}$} & $\begin{array}{l}\text { Demand for } \\
\text { variability in } \\
\text { production }\end{array}$ & Low, High & \multirow[t]{2}{*}{ Leanness ${ }^{* *},\{\},\{\}$, Agility** } & \\
\hline & $\begin{array}{l}\text { Demand for } \\
\text { variability of } \\
\text { products }\end{array}$ & Low, High & & \\
\hline \multirow[t]{2}{*}{$\begin{array}{l}\text { Mason-Jones } \\
\text { et al. (2000a) }\end{array}$} & Market & $\begin{array}{l}\text { Qualifiers, } \\
\text { Winners }\end{array}$ & \multirow[t]{2}{*}{$\begin{array}{l}\text { Quality/Lead-time/Service level***, Cost***, } \\
\text { Quality/Cost/Lead-time****, Service level*** }\end{array}$} & \\
\hline & Supply & Lean, Agile & & \\
\hline \multirow{2}{*}{$\begin{array}{l}\text { Christopher } \\
(2000)\end{array}$} & Volume & Low, High & \multirow[t]{2}{*}{}, Lean $^{* *}$, Agile**, \{\} & \\
\hline & $\begin{array}{l}\text { Variety/ } \\
\text { Variability }\end{array}$ & Low, High & & \\
\hline \multirow[t]{2}{*}{ Lee (2002) } & $\begin{array}{l}\text { Demand } \\
\text { uncertainty }\end{array}$ & Low, High & \multirow[t]{2}{*}{ Risk-hedging**, Agile**, Efficient**, Responsive ${ }^{* *}$} & \\
\hline & $\begin{array}{l}\text { Supply } \\
\text { uncertainty }\end{array}$ & Low, High & & \\
\hline \multirow[t]{2}{*}{$\begin{array}{l}\text { Olhager } \\
\text { (2003) }\end{array}$} & $\begin{array}{l}\text { Production-to- } \\
\text { delivery(P/D)- } \\
\text { ratio }\end{array}$ & $\mathrm{P} / \mathrm{D}<1, \mathrm{P} / \mathrm{D}>1$ & \multirow[t]{2}{*}{$\begin{array}{l}\text { MTO/(ATO)/MTS**, MTS** (make-to-stock), } \\
\text { MTO** (make-to-order), ATO** (assemble-to- } \\
\text { order) }\end{array}$} & \\
\hline & $\begin{array}{l}\text { Relative demand } \\
\text { volatility }\end{array}$ & Low, High & & \\
\hline \multirow[t]{2}{*}{$\begin{array}{l}\text { Aitken et al. } \\
\text { (2005) }\end{array}$} & $\begin{array}{l}\text { Market } \\
\text { requirements }\end{array}$ & $\begin{array}{l}\text { Market-qualifiers, } \\
\text { Order-winners }\end{array}$ & \multirow[t]{2}{*}{$\begin{array}{l}\text { Quality/Reliability***, Price***, Quality/ } \\
\text { Reliability***, Lead-time**** }\end{array}$} & \\
\hline & $\begin{array}{l}\text { Supply chain } \\
\text { focus }\end{array}$ & $\begin{array}{l}\text { Lean supply, Agile } \\
\text { supply }\end{array}$ & & \\
\hline \multirow{4}{*}{$\begin{array}{l}\text { Lovell et al. } \\
\text { (2005) } \\
\text { Christopher } \\
\text { et al. }(2006)\end{array}$} & Value-density & Low, High & \multirow{4}{*}{$\begin{array}{l}\text { Generic framework. Specific SCD depends on } \\
\text { detailed examination of business case. } \\
\text { Lean (continuous replenishment)**, Agile (quick } \\
\text { response)**, Lean (plan and execute)**, Leagile } \\
\text { (postponement)** }\end{array}$} & \\
\hline & Throughput & Low, High & & \\
\hline & $\begin{array}{l}\text { Demand } \\
\text { characteristics }\end{array}$ & $\begin{array}{l}\text { Predictable, } \\
\text { Unpredictable }\end{array}$ & & \\
\hline & $\begin{array}{l}\text { Supply } \\
\text { characteristics }\end{array}$ & $\begin{array}{l}\text { Short lead-time, } \\
\text { Long lead-time }\end{array}$ & & \\
\hline \multirow{3}{*}{$\begin{array}{l}\text { Vonderembse } \\
\text { et al. }(2006)\end{array}$} & Product type & Standard, & \multirow{3}{*}{$\begin{array}{l}\text { Lean** for standard, Agile** for innovative } \\
\text { (introduction, growth), Hybrid/Lean** for } \\
\text { innovative (maturity, decline), Hybrid** } \\
\text { (postponement) for hybrid }\end{array}$} & \\
\hline & & $\begin{array}{l}\text { Innovative, } \\
\text { Hybrid }\end{array}$ & & \\
\hline & Product life cycle & $\begin{array}{l}\text { introduction, } \\
\text { Growth, Maturity, } \\
\text { Decline }\end{array}$ & & \\
\hline \multirow{3}{*}{$\begin{array}{l}\text { Roh et al. } \\
\text { (2014) }\end{array}$} & Market & Order-qualifiers, & \multirow{3}{*}{$\begin{array}{l}\text { Quality/Lead-time/Service level***, Cost***, } \\
\text { Quality/Lead-time/Cost/Service level***, } \\
\text { Innovative features**** }\end{array}$} & \\
\hline & $\begin{array}{l}\text { requirements } \\
\text { Supply chain }\end{array}$ & $\begin{array}{l}\text { Order-winners } \\
\text { Lean supply, }\end{array}$ & & \\
\hline & focus & responsive supply & & Select strategy \\
\hline \multicolumn{4}{|c|}{ Notes: *Segments; $* *$ Strategies; $* * *$ Competitive priorities; \{\}$=$ empty set } & typologies \\
\hline
\end{tabular}


JDAL 4,2

relative demand volatility, Olhager (2003) proposes CODP-based SCSs. Vonderembse et al. (2006) expand previous contributions by introducing the product life cycle and more than two values for each dimension. Table 1 summarises a selection of strategy typologies. The selection is not exhaustive but incorporates all SCD constructs of interest to the study. It includes seminal contributions, for example, Fisher (1997), and extensions, for instance, Lee (2002). It also exemplifies other perspectives on strategy typologies, such as Olhager (2003) and Lovell et al. (2005).

With the exception of Vonderembse et al. (2006), the contributions in Table 1 are two-bytwo matrices, with two dimensions, two values each and four segments. However, two models (Naylor et al., 1999; Christopher, 2000) are dichotomies, whereas the others are quadripartites. Vonderembse et al. (2006) propose a three-by-four matrix but merge the segments and provide a selection of four strategies. Empirical research to test these typologies has been mixed, inconclusive or negative (Perez-Franco et al., 2016; Basnet and Seuring, 2016). Testing Fisher's model, Selldin and Olhager (2007) find that a match between products and SCs do not necessarily outperform mismatches.

2.2.2 Strategy continuums. Researchers have criticised strategy typologies for being too simplistic (Godsell et al., 2006; Hilletofth, 2012; Basnet and Seuring, 2016). As customers may require different degrees of responsiveness (Collin et al., 2009), researchers should present strategies in a continuum (Basnet and Seuring, 2016). Even if the typologies in Table 1 present discrete choices, some authors discuss continuums. Naylor et al. (1999) conclude that lean and agile are complementary strategies and that companies should strive for "leagility", by combining lean and agile in a total SCS through an appropriate CODPpositioning. One of the SCSs proposed by Christopher et al. (2006) is leagile, which is a continuum. Olhager (2003) propose a subset of a strategy continuum.

The CODP is an important construct in SCD, and its positioning is a strategic decision (Olhager, 2003; Yang and Burns, 2003). It primarily relates to the competitive priority delivery speed (Olhager, 2003) and SCD should position it based on which lead-time that is acceptable to the customer (Naylor et al., 1999). Sharman (1984) introduces it into logistics and proposes five strategies, sell from stock (make-to-stock [MTS]), sell semi-customised system from stock, assemble and sell from stock of parts, make-to-order (MTO) and design and MTO. Authors have since re-labelled and extended, by introducing more CODPs and combining it with strategy typologies. Naylor et al. (1999) describe five CODP-based SCSs, buy-to-order (BTO), MTO, assemble-to-order (ATO), MTS and ship-to-stock. Olhager (2003) define four CODP-related SCSs, MTS, ATO, MTO and engineer-to-order (ETO). Building on the standardisation-customisation continuum (Lampel and Mintzberg, 1996), Yang and Burns (2003) propose an integrated framework, dividing speculation and postponement and standardisation and customisation. They define seven SCSs based on the CODP-position, make-to-forecast (MTF/MTS), shipment-to-order (STO), packaging/labelling-to-order (PTO), ATO, MTO, BTO and ETO. Yang et al. (2004) combine the framework proposed by Yang and Burns (2003) with three additional spectra, lean-leagile-agile, globalisationglocalisation-localisation and centralisation-decentralisation. Table 2 illustrates select strategy continuums.

The extreme points in these spectra are pure postponement (ETO) and pure speculation (MTF). ETO enables pure customisation, agility and responsiveness but entails extensive lead-times. MTF facilitates pure standardisation, leanness and efficiency but involves increased costs for storage and risk-taking regarding misjudged future demand, depreciation and obsolescence. In between these extremes, there are five hybrid strategies, representing postponement of one, or more, of the activities that manufacturers and distributors must perform. The hybrid strategies, BTO, MTO, ATO, PTO and STO, are 


\begin{tabular}{|c|c|c|c|c|c|c|}
\hline SCS & CODP-position & $\begin{array}{l}\text { Push-pull } \\
\text { boundary }\end{array}$ & $\begin{array}{l}\text { Postponement- } \\
\text { Speculation }\end{array}$ & $\begin{array}{l}\text { Agile-leagile- } \\
\text { lean }\end{array}$ & $\begin{array}{l}\text { Customisation- } \\
\text { standardisation }\end{array}$ & $\begin{array}{l}\text { Defence } \\
\text { supply chain }\end{array}$ \\
\hline ETO & Before design & $\begin{array}{l}\text { Engineering } \\
\text { (pull-only) }\end{array}$ & $\begin{array}{l}\text { Pure (full) } \\
\text { postponement }\end{array}$ & $\begin{array}{l}\text { Agile } \\
\text { (responsive) }\end{array}$ & Pure customisation & \\
\hline BTO & $\begin{array}{l}\text { Before } \\
\text { purchasing }\end{array}$ & Purchasing & $\begin{array}{l}\text { Purchasing } \\
\text { postponement }\end{array}$ & Leagile & Tailored customisation & \\
\hline MTO & $\begin{array}{l}\text { Before } \\
\text { manufacturing }\end{array}$ & Manufacturing & $\begin{array}{l}\text { Manufacturing } \\
\text { postponement }\end{array}$ & Leagile & Tailored customisation & 189 \\
\hline ATO & Before assembly & Assembly & $\begin{array}{l}\text { Assembly } \\
\text { postponement }\end{array}$ & Leagile & $\begin{array}{l}\text { Customised } \\
\text { standardisation }\end{array}$ & \\
\hline PTO & $\begin{array}{l}\text { Before } \\
\text { packaging }\end{array}$ & Packaging & $\begin{array}{l}\text { Packaging } \\
\text { postponement }\end{array}$ & Leagile & $\begin{array}{l}\text { Customised } \\
\text { standardisation }\end{array}$ & \\
\hline STO & $\begin{array}{l}\text { Before } \\
\text { distribution }\end{array}$ & Distribution & $\begin{array}{l}\text { Logistics } \\
\text { postponement }\end{array}$ & Leagile & $\begin{array}{l}\text { Segmented } \\
\text { standardisation }\end{array}$ & \\
\hline MTF & $\begin{array}{l}\text { After } \\
\text { distribution }\end{array}$ & $\begin{array}{l}\text { Storage (push- } \\
\text { only) }\end{array}$ & Pure (full) speculation & $\begin{array}{l}\text { Lean } \\
\text { (efficient) }\end{array}$ & Pure standardisation & \\
\hline \multicolumn{6}{|c|}{$\begin{array}{l}\text { Sources: Lampel and Mintzberg (1996), Fisher (1997), Pagh and Cooper (1998), Yang and Burns (2003), } \\
\text { Yang et al. (2004), Christopher et al. (2006) }\end{array}$} & $\begin{array}{r}\text { Select strategy } \\
\text { continuums }\end{array}$ \\
\hline
\end{tabular}

leagile, enabling varying degrees of customisation/standardisation, agility/leanness and responsiveness/efficiency. All activities that take place prior to a customer order is speculation by the manufacturer, involving risk-taking. The CODP-positioning thus separates decisions under uncertainty from decisions under certainty, speculation from postponement and push from pull and impacts costs, lead-times and risk-taking. Strategy continuums raise the question, "at what point or combination of points in the SC postponement provides the greatest overall benefit” (Boone et al., 2007).

2.2.3 Supply chain design constructs. Strategy typologies and continuums share constructs, such as external contingencies, competitive priorities and SCSs. External contingencies are the product/market requirements in SCD (Basnet and Seuring, 2016). Christopher et al. (2009) propose five external contingencies: duration of life cycle, delivery lead-time, volume, product variety and variability in demand, supply or process. Basnet and Seuring (2016) condense the 14 most frequent contingencies in the literature into 4: demand variability/uncertainty, product variety, desired customer lead-time and supply uncertainty/ risk. When a company focusses on the end-user, it must consider all competitive priorities, such as service, quality, cost and lead-time (Naylor et al., 1999) and make trade-offs between contesting competitive priorities (Basnet and Seuring, 2016). Table 3 summarises the commercial SCD constructs that this paper investigates in defence and exemplifies definitions.

\section{Research methodology}

RAND developed the Delphi method in the 1950s (Dalkey and Helmer, 1963). The method is iterative, allows anonymous collaboration between experts (Okoli and Pawlowski, 2004) and includes gathering opinions from experts, synthesising and statistically summarising opinions and providing feedback. It is applicable in most areas (Linstone and Turoff, 2002, p. 3) and appropriate when expert opinions are the only available source of information. As this study is on defence SCD, an area with insufficient academic knowledge and where expert opinions and proven experience are the primary sources of information, the researchers selected the Delphi method. 


\section{JDAL 4,2}

190

\section{Commercial SCD constructs Select definitions}

CODP

Competitive priorities

Cost

Delivery/Lead-time

Dependability

Flexibility

Quality

External contingencies

Separates forecast and order-driven activities (Mason-Jones et al., 2000b)

Manufacturers' choice of tasks or key competitive capabilities (Chen and Paulraj, 2004)

Logistics costs, infrastructure, inventory (Schnetzler et al., 2007)

Delivery-times, high fill rate (Schnetzler et al., 2007)

Punctuality, delivery reliability rate (Schnetzler et al., 2007)

Managing changes and uncertainties (Schnetzler et al., 2007)

Meeting higher customer demands (Schnetzler et al., 2007)

Product/market requirements (exogenous variables) in SCD (Basnet and Seuring, 2016)

Demand variability/uncertainty The inability to forecast product demand accurately (Basnet and Seuring, 2016)

Desired customer lead-time

Product variety

The importance placed by the customer on quick delivery (Basnet and Seuring, 2016)

Supply uncertainty/risk

Products may be characterised as standardised (low variety) or customised (high variety) (Basnet and Seuring, 2016)

Disruptions by various causes, such as natural disasters, yield losses, quality issues, etc. (Basnet and Seuring, 2016)

SC strategies

Specifies how a company can achieve its competitive advantage through its competitive priorities (Qi et al., 2011)

Agility

Efficiency

ETO, BTO, MTO, ATO, PTO, STO, MTF/MTS

Full (pure) postponement

Full (pure) speculation

The ability to respond rapidly to unpredictable changes in demand or supply (Christopher and Peck, 2004)

Distinguished by longer production lead-times, high set-up costs and larger batch sizes that allow the efficient firm to produce at a low unit cost but often at the expense of market responsiveness (Randall et al., 2003)

Involves postponement of design (ETO), purchasing (BTO), manufacture (MTO), assembly (ATO), packaging (PT0) and/or shipment (STO) or pure speculation (MTF/MTS) (Yang et al., 2004)

Both manufacturing and logistics activities are customer order initiated (Pagh and Cooper, 1998)

Based on forecasts involves full speculation of all manufacturing and logistics activities (Pagh and Cooper, 1998)

Leagility

Leanness Judicious selection and integration of appropriate aspects of lean and agile (Christopher et al., 2006)

Means developing a value stream to eliminate all waste, including time, and to ensure a level schedule (Naylor et al., 1999)

Logistics postponement Direct distribution of finished goods from centralised inventory (Pagh and Cooper, 1998)

Manufacturing postponement Final manufacturing activities performed downstream in the SC (Pagh and Cooper, 1998)

Responsiveness

Distinguished by short production lead-times, low set-up costs and small batch sizes that allow the responsive firm to adapt quickly to market demand but often at a higher unit cost (Randall et al., 2003)

Commercial SCD constructs and select Risk-hedging definitions
Aimed at pooling and sharing resources to enable risk sharing in supply disruption (Lee, 2002)

The Delphi method has been critiqued for lacking scientific rigour and for questionable application (Sackman, 1974), which has led to epistemological debate (Hasson and Keeney, 2011) and practical guidelines, such as Worrell (2013). This paper describes a modified, conventional Delphi in line with Worrell (2013) and demonstrates trustworthiness in line with Skulmoski et al. (2007). The study included a literature review to identify seeds, a three- 
round Delphi study, with workshops to review and extend the findings (Melnyk et al., 2009), and strategy formulation.

The researchers conducted the Delphi study in six steps: panel selection, introduction, Delphi rounds 1-3 and workshops. The study invited 45 practitioners from the Swedish Armed Forces (SwAF) and the Swedish Defence Materiel Administration (FMV), and researchers from the Swedish Defence Research Agency (FOI) and the Swedish National Defence University (SEDU). The 25 experts who accepted the invitation represent different perspectives (Melnyk et al., 2009) and have experience in excess of 20 years. Five experts left the study before the first round. The final panel consisted of 12 experts from the SwAF, 4 from FMV and 2 researchers each from FOI and SEDU. The panellists had no knowledge of the number or identity of participants. The researchers distributed written information to each panellist, presenting the study, its background and objective and summarising the Delphi method. The response rates in the three rounds were $100 \%, 85 \%$ and $75 \%$.

In the first round, the panellists answered 12 questions concerning the acceptability and applicability of commercial SCD constructs in defence on a five-level Likert scale, ranging from "strongly disagree" to "strongly agree". They could justify answers, motivate abstainment and comment on omitted issues, in free text. For each round, the researchers compiled and analysed answers to determine whether to alter, delete or add questions. No insights motivated changes for the second round. In the second round, the panellists received a compilation of answers, including most frequent answers, means, justifications and motivations, which enabled them to change answers based on this information. The few revisions reinforced the most frequent answers and reduced means but did not provide new insights. The study thus changed the format for the third round and asked the panellists to answer "Yes", "No" or "I don't know". For most questions, Round 3 led to consensus. However, for some questions, there was bipolarity, which researchers and panellists addressed during the workshops. The workshop participants also discussed if and how the investigated constructs could describe previous logistics systems in the SwAF. The second workshop used the results of the first as input, allowing discussions to commence on a higher level of understanding.

After the workshops, the researchers formulated eight SCSs, based on the literature and the study's results, and distributed them to the panel for validation and comments. There was consensus that the eight SCSs are acceptable, applicable and sufficient to satisfy the Swedish defence authorities' operational requirements.

\section{Research results}

The purpose of this paper is to explain the constructs of SCSs that satisfy military operational requirements and to propose SCSs that are appropriate in defence. This section establishes the operational requirements, determines acceptability, applicability and sufficiency of commercial SCD constructs $(R Q 1)$ and proposes acceptable, applicable and sufficient defence SCSs $(R Q 2)$.

\subsection{Operational requirements}

The researchers asked the panellists if the study should base defence SCSs on commercial or operational goals. In the first round, there was a consensus regarding using operational goals. One panellist stressed the importance:

For us as a buyer it is important that the right product, with the right quality, is delivered in time to serve our purpose. Unfortunately, I have found that the suppliers often fail in this regard. 
JDAL 4,2

Another panellist noted, "It is only reasonable to base it on factors that are important to us if it is going to be useful to us".

During the workshops, the panellists agreed that the study should operationalise the SwAF's unique SCD issues through operational requirements on logistics, derived from Sweden's Defence Policy (The Swedish MoD, 2015). It specifies the operational outcome that the SCs must contribute to in terms of availability, preparedness and sustainability. The SwAF's main task in peace is to maintain availability and preparedness (The Swedish MoD, 2015, p. 6), and the government differentiates these requirements between military units. There are three values for availability: immediately, within three months or within six months, and three for preparedness: mobilisation within hours, days or within one week. These requirements provide a starting point for the requirements on sustainability. The requirements on availability and preparedness provide a few days of supplies. The requirements on sustainability involve a flow of replacement supplies throughout an operation.

\subsection{Acceptability, applicability and sufficiency of commercial supply chain design constructs}

This study introduces commercial SCD constructs into Swedish defence. For many panellists, it provided the first encounter with an alien terminology, even if phenomena were familiar. For some constructs, there was initial resistance. The following comments illustrate attitudes regarding CODP. "I don't think that CODP is relevant in military logistics". "I guess it's OK, but CODP is a new concept to most of us in the SwAF, and may cause confusion for many". "Military terminology should be used". However, some saw potential. "The concept is very suitable. It could provide a switching point in a flow from strategic, via operational and tactical, to the combat level". Acceptance increased during the study, and by the third round, a qualified majority accepted the CODP as applicable in defence SCD. During the workshops, there was consensus that it is a useful construct to differentiate defence SCs, and that the study should use the CODP to propose defence SCSs. This means that the panellists require a strategy continuum rather than a typology.

For each SCD construct in Table 3, the study asked the panellists to answer if they are acceptable and applicable for defence SCD. Table 4 summarises the results from Round 3 and the workshops and exemplifies comments from the initial rounds. The comments demonstrate diverging opinions in the study's early stages. However, for most questions, by Round 3, there was agreement that the investigated constructs are acceptable and applicable for defence SCD. The notable exceptions were the questions related to postponement and speculation. "Postponement feels relevant, but speculation gives a feeling of gambling". "Entirely civilian concepts, with few connections to military activities". "It doesn't seem likely that these concepts contribute to the overarching objective; to win the war". However, some panellists were positive. One stated, "Both terms are required to handle different supply classes", and another that "They are needed to design military SCs". One panellist observed, "Speculation from a civilian perspective could be security-of-supply from a military perspective". Some positive comments came with a constraint, "The names should be militarised if these strategies are going to be used in the SwAF".

During the workshops, the participants discussed the logistics systems that supported the national defence during the Cold War and the expeditionary forces after the Cold War. They concluded that the commercial SCD constructs are useful to describe these systems. Agility, responsiveness, safety stock, speculation and decentralisation describe national defence logistics. Leanness, efficiency, pooling and sharing, postponement and centralisation describe expeditionary logistics. The participants agreed that all investigated constructs are acceptable and applicable in defence SCD. However, they also agreed that the 


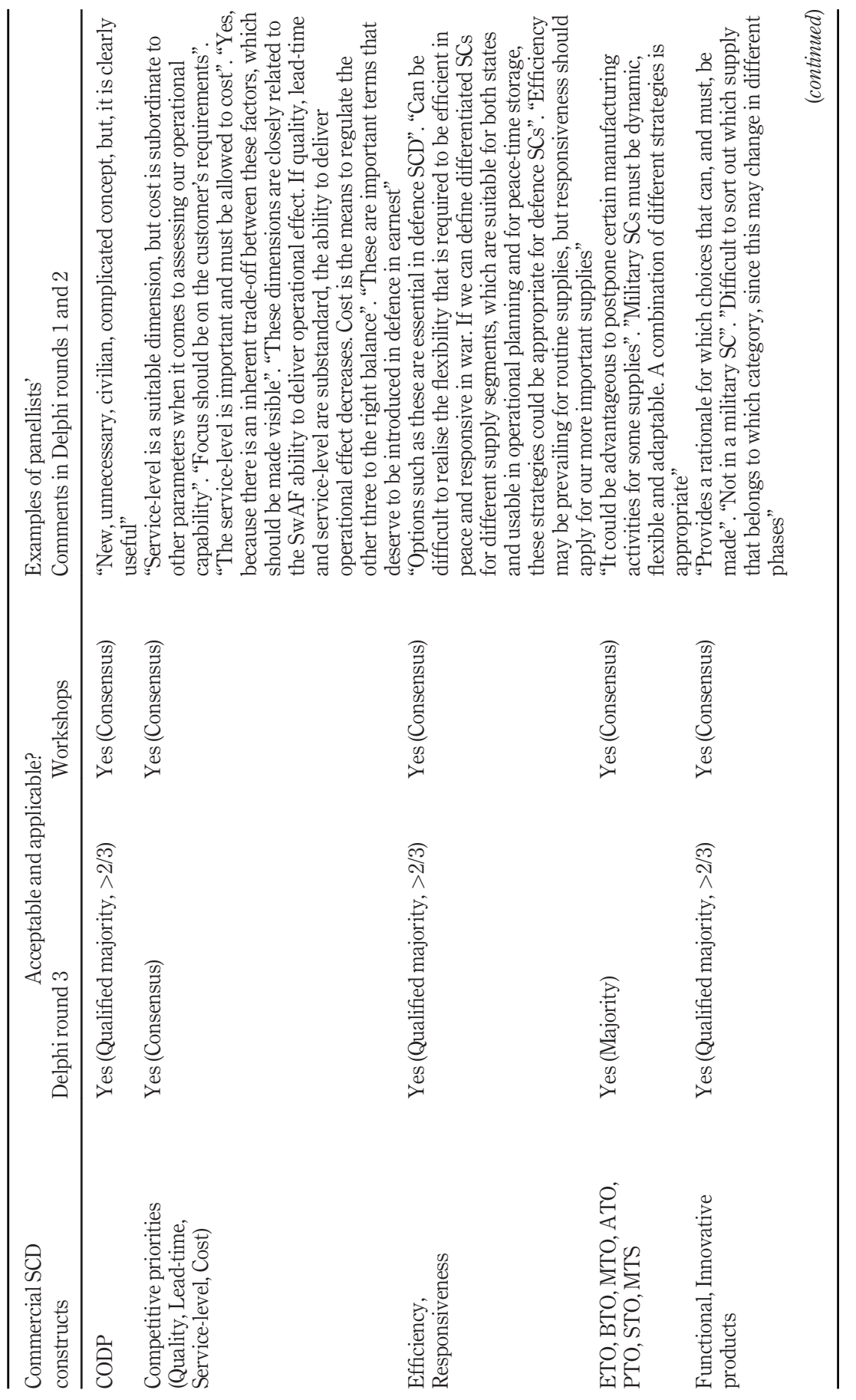

Table 4. Results from the Delphi study 
$\underset{4,2}{\text { JDAL }}$

194

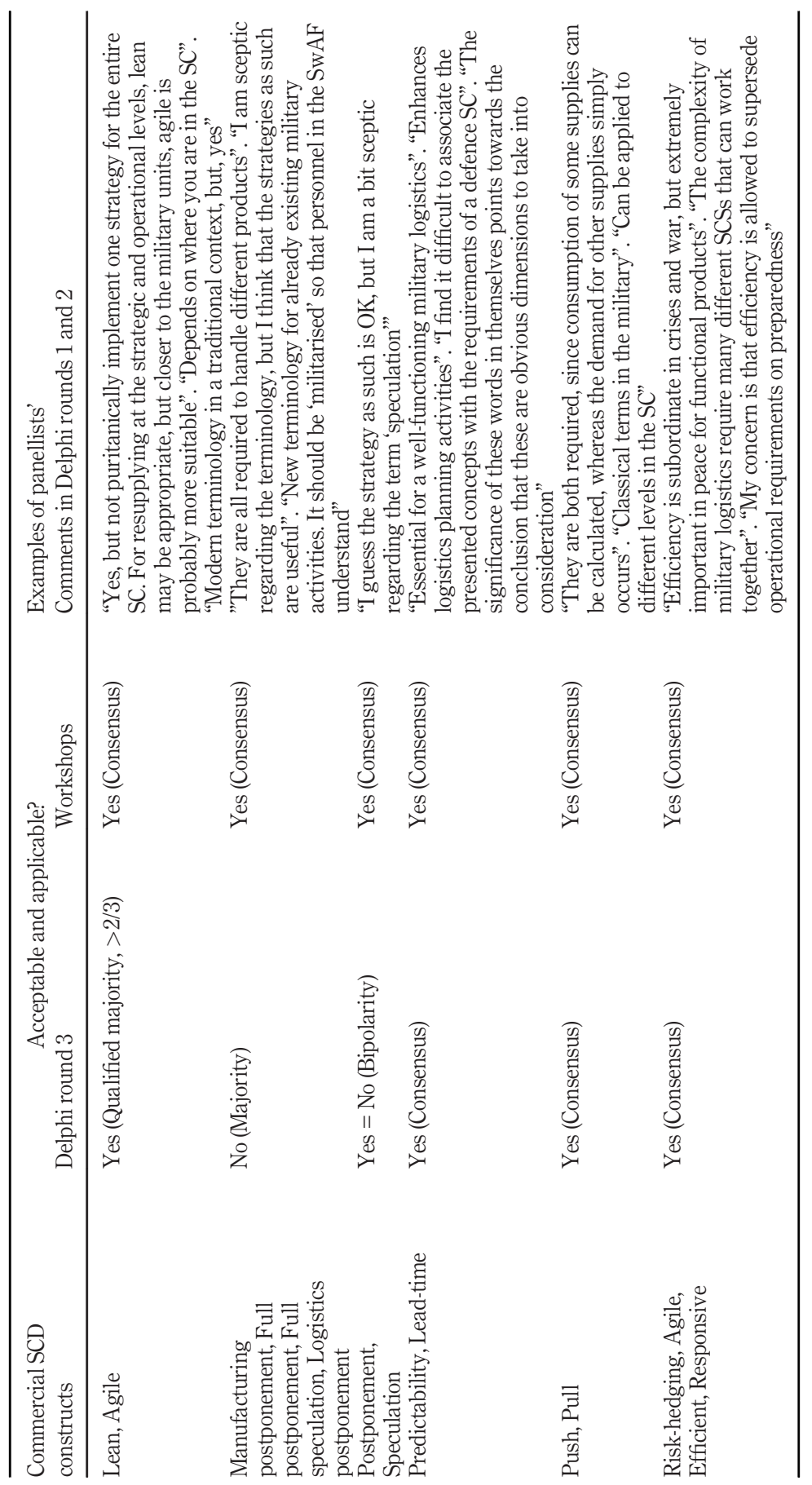

Table 4. 
researchers should develop a CODP-based strategy continuum for defence SCD, as a strategy typology would not be sufficient.

\subsection{Acceptable, applicable and sufficient defence supply chain strategies}

The panellists concluded that the SCSs in Table 2 are acceptable and applicable in defence SCD. Accordingly, a spectrum of seven CODP-based SCSs are available to ensure that supply meets demand. However, not all SCSs are applicable for all operational requirements. In addition, they are not sufficient. For these panellists, the importance of lead-time is paramount from an operational perspective. SCD must position the CODP so that the expected lead-time from order to delivery is within the operational requirements' limits. If defence authorities cannot accept the risk that suppliers fail to deliver on time, they must procure and store supplies in-house to guarantee the satisfaction of all operational requirements. This paper defines this alternative as pre-storage or procure-to-stock (PTS) and proposes eight SCSs that are acceptable, applicable and sufficient in defence SCD. The first seven SCSs use names from the literature, from a supplier's perspective. However, ETO, BTO, MTO, ATO, PTO, STO and MTS work equally well from a buyer's perspective, as buyers can contract suppliers to differentiate SCSs to satisfy their requirements. ETO is applicable for capability development (CAPDEV), which involves the development of new, technically advanced systems but not for operational requirements. Depending on lead-time, BTO, MTO, ATO, PTO, STO and MTS may be expedient to satisfy some operational requirements but not all. PTS is applicable for all operational requirements and may be necessary to satisfy immediate availability and preparedness and to ensure sustainability until industry commences delivering replacement supplies. However, in addition to costs for procurement, operations, maintenance, infrastructure, distribution and personnel, PTS involves risk-taking regarding depreciation and obsolescence and should be used restrictively. To minimise lead-times, defence authorities should combine PTS with prepositioning, close to planned locations for activation and mobilisation for supplies required for immediate availability and preparedness and close to envisioned areas of operations for supplies required for sustainability. Table 5 matches CAPDEV and the SwAF's operational requirements with the proposed SCSs.

The lead-time from order to delivery for military-specific supplies ranges from hours to years, depending on supply class and SCS. The point in time at which the SwAF require replacement supplies depends on consumption patterns, which in turn depend on time, activity, chance or a combination. Consequently, Table 5 is illustrative not prescriptive. It is not a decision-making tool but serves as an illustration of which SCS that may be applicable. Prior to any decisions, defence authorities must analyse the different supply classes and, in some cases, individual supply items, to determine applicable SCSs, for each operational requirement. For a specific supply item, a combination of SCSs will probably be required to satisfy all requirements. In addition to matches and mismatches, which are certainties, Table 5 includes potential matches, which are uncertainties. Potential matches illustrate that a certain combination of operational requirement and SCS may be a match, depending on lead-time and consumption pattern.

\section{Discussion}

The purpose of this paper is to explain the constructs of SCSs that satisfy military operational requirements and to propose SCSs that are appropriate in defence. $R Q 1$ asks how acceptable, applicable and sufficient commercial SCD constructs, such as external contingencies, competitive priorities and SCSs, are in defence. The study concludes that all investigated constructs are acceptable and applicable but not sufficient. Even if the
Defence
supply chain
design

195 
JDAL

4,2

196

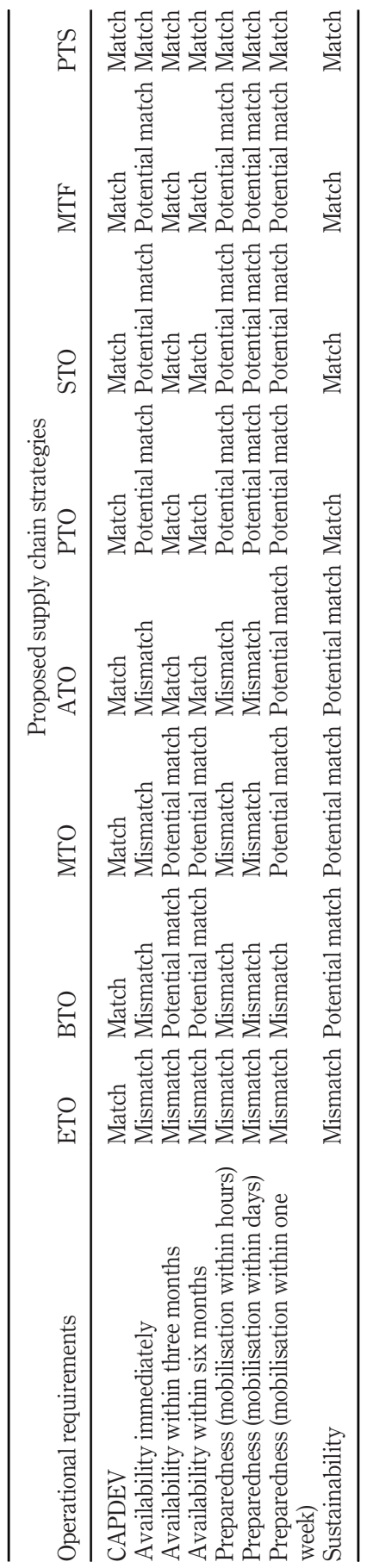

Table 5.

Operational

requirements versus

proposed supply

chain strategies 
constructs are acceptable and applicable, the findings indicate that in defence, operational requirements have different implications for competitive priorities in peace, mobilisation and war. Aitken et al. (2005) suggest that market-qualifying and order-winning characteristics may change as a function of the product life cycle. The findings indicate that a better distinction in defence SCD is between peace, mobilisation and war. To satisfy requirements on availability and preparedness, quality, lead-time, flexibility and dependability are market qualifiers, but the cost is the likely order-winner, which means that SCs should be lean (Aitken et al., 2005; Kovács and Tatham, 2009). For sustainability, leadtime is all-important or the order-winner. In such cases, SCD should position the CODP based on which lead-time that is acceptable to the customer (Naylor et al., 1999), which is likely to be close to the final goods inventory (Olhager, 2003), and the SC should be agile (Aitken et al., 2005; Kovács and Tatham, 2009). Basnet and Seuring (2016) conclude that demand variability/uncertainty, product variety, desired customer lead-time and supply uncertainty/risk represent the essential contingencies in SCD. The findings indicate that in defence, the values will change between peace, mobilisation and war. Demand variability/ uncertainty will go from low to high, desired customer lead-time will go from subordinate to cost, to all-important, and supply uncertainty/risk will increase in war. Defence SCD must consider these unique issues when selecting appropriate SCSs. This dynamic epitomises the defence SCD-dilemma, which companies and authorities must resolve. Lean and efficient in peace and agile and effective in war.

$R Q 2$ asks which SCSs satisfy defence authorities' operational requirements. In line with Hilletofth (2012) and Basnet and Seuring (2016), the panellists find strategy typologies too simplistic for their requirements and determine that defence authorities must develop a strategy continuum, based on CODP-positioning. This paper proposes eight SCSs that are acceptable, applicable and sufficient for defence SCD. Seven are in line with suggestions in the literature, such as Yang et al. (2004). The eighth is a complement, as SCs may not always be able to satisfy operational requirements, in which case defence authorities must pre-store supplies, using the PTS strategy. The answer to which SCS to select, or at what point in the defence SC the CODP delivers the maximum advantage (Boone et al., 2007), is that it depends. Armed forces require various supply classes, including market-generic and military-specific, with lead-times ranging from hours to years. In addition, consumption patterns depend on time, activity, chance or a combination, which means that for some supply classes, demand is unpredictable. Depending on supply class and which operational requirement that is to be satisfied, different SCSs will be applicable. This means that a dynamic application of SCSs is required in defence SCD. Contrary to most commercial SCs, for a particular supply item, it is likely that several SCSs are required to satisfy the different operational requirements. PTS satisfies all operational requirements but is costly and associated with financial and technical risk-taking. Defence authorities must thus identify the optimal mix of SCSs, which satisfies operational requirements at minimum cost and technical risk, without unwarranted operational risk-taking. To select appropriate SCSs, defence authorities' will require a segmentation model, which classifies supplies based on operational requirements.

For every SCS proposed in this paper, variants are possible. An SCS is a configuration of decisions regarding sourcing, capacities, manufacturing and distribution (Hilletofth, 2009). The eight SCSs position the CODP at various points in the SC, thus postponing different process-related decisions, but there are other issues to consider. These include customisation/standardisation of products, centralisation/decentralisation of production, globalisation/localisation of sourcing, storage and distribution, strategic inventories other than at the CODP, strategic capacity positioning, transportation modes and $\mathrm{SC}$ relationships
Defence
supply chain
design

197 
JDAL 4,2

(Yang et al., 2004; MacCarthy et al., 2016). Defence authorities can complement the eight SCSs by contracting suppliers to reduce lead-times, with measures such as storing raw materials, components or sub-systems, decentralising production, localising sourcing, storage and distribution and/or increasing capacities. Such measures must also be included in the analysis required to identify the optimal mix of SCSs for all supply classes and all operational requirements. In addition, defence authorities can use performance-based logistics (PBL) to contract suppliers to deliver availability of supplies rather than traditional, transaction-based contracts.

\section{Conclusions, implications and further research \\ 6.1 Conclusions}

To explain the constructs of SCSs that satisfy operational requirements, this paper investigates the acceptability, applicability and sufficiency of commercial SCD constructs in the Swedish defence and concludes that they are acceptable and applicable but not sufficient. The findings indicate that defence authorities prefer strategy continuums to typologies, as continuums are better suited to meet their requirements. Furthermore, an additional SCS is required. As well as proposing seven strategies from the literature (Yang et al., 2004), this paper proposes a complementary strategy for pre-storage, procure-to-stock (PTS).

\subsection{Implications}

The results presented in this paper have implications for managers in companies and defence authorities. For companies, this paper emphasises that defence authorities' operational requirements are different in peace, mobilisation and war and that they can develop SCSs accordingly. For defence authorities, it exemplifies how they should formulate their unique SCD issues and articulate their requirements on SCD. PTS is a match for all operational requirements but unaffordable to implement as the only SCS and associated with financial and technical risk-taking. Defence authorities should use it restrictively, when it is required to avoid operational risk-taking.

\subsection{Future research}

This paper proposes eight generic SCSs that are acceptable, applicable and sufficient in defence SCD but does not answer the question when to use which strategy. SCSs are one element of purchasing portfolio models (PPMs), where the others are a segmentation model and guidance for management decisions. This paper suggests that future research completes a PPM for defence procurement by developing the remaining elements. It would also be interesting with further research regarding variants of the generic strategies, such as PBL.

Researchers such as Mason-Jones et al. (2000b) and Aitken et al. (2005) have explored the concept of market-qualifiers and order-winners in the private sector, where commercial outcomes are important. It would be interesting to explore these concepts in the public sector, where operational outcomes are the focus. The results from this study indicate that in defence, there may be different sets of market-qualifiers and order-winners for peace, mobilisation and war, and it would be of interest to do further research on this topic.

Glas (2017) discusses the issues of the preferred customer, customer attractiveness and preferential treatment of military customers in peace. This paper suggests that defence SCD must take into consideration that suitable competitive priorities, and hence SCSs, are different in peace, mobilisation and war. It would be interesting to investigate preferential 
treatment in higher levels of conflict and preparedness, when military customers may stand against each other, and any consequences that this may have for SCD.

The results presented in this paper comes from a Delphi study in the Swedish defence. To determine generalisability, additional studies are required. This paper suggests that researchers conduct studies with other methods and stakeholders, in other contexts, including different national perspectives. In particular, this paper invites researchers to explore the validity of the eight proposed SCSs in other defence settings.

\section{References}

Aitken, J., Childerhouse, P., Christopher, M. and Towill, D. (2005), "Designing and managing multiple pipelines", Journal of Business Logistics, Vol. 26 No. 2, pp. 73-96.

Basnet, C. and Seuring, S. (2016), "Demand-oriented supply chain strategies - a review of the literature", Operations and Supply Chain Management: An International Journal, Vol. 9 No. 2, pp. 73-89, doi: 10.31387/oscm0240162.

Betts, R. (1995), Military Readiness: Concepts, Choices, Consequences, Brookings Institution, Washington, DC.

Boone, C., Craighead, C. and Hanna, J. (2007), "Postponement: an evolving supply chain concept", International Journal of Physical Distribution and Logistics Management, Vol. 37 No. 8, pp. 594-611.

Chen, I. and Paulraj, A. (2004), "Towards a theory of supply chain management: the constructs and measurements", Journal of Operations Management, Vol. 22 No. 2, pp. 119-150.

Christopher, M. (2000), "The agile supply chain competing in volatile markets", Industrial Marketing Management, Vol. 29 No. 1, pp. 37-44.

Christopher, M. and Peck, H. (2004), "Building the resilient supply chain", The International Journal of Logistics Management, Vol. 15 No. 2, pp. 1-14.

Christopher, M., Peck, H. and Towill, D. (2006), “A taxonomy for selecting global supply chain strategies", The International Journal of Logistics Management, Vol. 17 No. 2, pp. 277-287.

Christopher, M., Towill, D., Aitken, J. and Childerhouse, P. (2009), "Value stream classification”, Journal of Manufacturing Technology Management, Vol. 20 No. 4, pp. 460-474.

Collin, J., Eloranta, E. and Holmström, J. (2009), "How to design the right supply chains for your customers", Supply Chain Management: An International Journal, Vol. 14 No. 6, pp. 411-417.

Dalkey, N. and Helmer, O. (1963), "An experimental application of the DELPHI method to the use of experts”, Management Science, Vol. 9 No. 3, pp. 458-467.

Davids, C., Beeres, R. and van Fenema, P. (2013), "Operational defense sourcing: organizing military logistics in Afghanistan", International Journal of Physical Distribution and Logistics Management, Vol. 43 No. 2, pp. 116-133.

Fisher, M. (1997), "What is the right supply chain for your product?", Harvard Business Review, Vol. 75 No. 2, pp. 105-116.

Glas, A. (2017), "Preferential treatment from the defense industry for the military", Journal of Defense Analytics and Logistics, Vol. 1 No. 2, pp. 96-119.

Glas, A., Hofmann, E. and Eßig, M. (2013), "Performance-based logistics: a portfolio for contracting military supply", International Journal of Physical Distribution and Logistics Management, Vol. 43 No. 2, pp. 97-115.

Godsell, J., Harrison, A., Emberson, C. and Storey, J. (2006), "Customer responsive supply chain strategy: an unnatural act?", International Journal of Logistics Research and Applications, Vol. 9 No. 1 , pp. $47-56$. 


\section{JDAL 4,2}

Gunasekaran, A., Lai, K. and Cheng, E. (2008), "Responsive supply chain: a competitive strategy in a networked economy”, Omega, Vol. 36 No. 4, pp. 549-564, doi: 10.1016/j.omega.2006.12.002.

Hasson, F. and Keeney, S. (2011), "Enhancing rigour in the delphi technique research", Technological Forecasting and Social Change, Vol. 78 No. 9, pp. 1695-1704.

Hauk, J. (1964), "Logistics and physical distribution management in the military", Transportation Journal, Vol. 4 No. 2, pp. 12-19.

Hilletofth, P. (2009), "How to develop a differentiated supply chain strategy", Industrial Management and Data Systems, Vol. 109 No. 1, pp. 16-33.

Hilletofth, P. (2012), "Differentiation focused supply chain design”, Industrial Management and Data Systems, Vol. 112 No. 9, pp. 1274-1291.

Jüttner, U., Peck, H. and Christopher, M. (2003), "Supply chain risk management: outlining an agenda for future research", International Journal of Logistics Research and Applications, Vol. 6 No. 4, pp. 197-210.

Kovács, G. and Tatham, P. (2009), "Responding to disruptions in the supply network - from dormant to action”, Journal of Business Logistics, Vol. 30 No. 2, pp. 215-229.

Lampel, J. and Mintzberg, H. (1996), “Customizing customization”, Sloan Management Review, Vol. 38 No. 1, pp. 21-30.

Lee, H. (2002), "Aligning supply chain strategies with product uncertainties”, California Management Review, Vol. 44 No. 3, pp. 105-119.

Linstone, H. and Turoff, M. (2002), "The Delphi method, techniques and applications", available at: https://web.njit.edu/ turoff/pubs/delphibook/delphibook.pdf (accessed 11 June 2020).

Lovell, A., Saw, R. and Stimson, J. (2005), "Product value-density: managing diversity through supply chain segmentation", The International Journal of Logistics Management, Vol. 16 No. 1, pp. 142-158.

McGinnis, M. (1992), "Military logistics: insights for business logistics", International Journal of Physical Distribution and Logistics Management, Vol. 22 No. 2, pp. 22-32.

MacCarthy, B., Blome, C., Olhager, J., Srai, J. and Zhao, X. (2016), "Supply chain evolution - theory, concepts and science", International Journal of Operations and Production Management, Vol. 36 No. 12, pp. 1696-1718.

Martel, A., Benmoussa, A., Chouinard, M., Klibi, W. and Kettani, O. (2013), "Designing global supply networks for conflict or disaster support: the case of the Canadian armed forces", Journal of the Operational Research Society, Vol. 64 No. 4, pp. 577-596.

Mason-Jones, R., Naylor, B. and Towill, D. (2000a), "Lean, agile or leagile? matching your supply chain to the marketplace", International Journal of Production Research, Vol. 38 No. 17, pp. 4061-4070.

Mason-Jones, R., Naylor, B. and Towill, D. (2000b), "Engineering the leagile supply chain”, International Journal of Agile Management Systems, Vol. 2 No. 1, pp. 54-61.

Melnyk, S., Davis, E., Spekman, R. and Sandor, J. (2010), "Outcome-driven supply chains", Sloan Management Review, Vol. 51 No. 2, pp. 32-38.

Melnyk, S., Lummus, R., Vokurka, R., Burns, L. and Sandor, J. (2009), "Mapping the future of supply chain management: a Delphi study", International Journal of Production Research, Vol. 47 No. 16, pp. 4629-4653.

Melnyk, S., Narasimhan, R. and DeCampos, H. (2014), "Supply chain design: issues, challenges, frameworks and solutions", International Journal of Production Research, Vol. 52 No. 7, pp. 1887-1896.

Moore, S., Stockfisch, J., Goldberg, M., Holroyd, S. and Hildebrandt, G. (1991), Measuring Military Readiness and Sustainability, Rand, Santa Monica, CA.

Nag, B., Han, C. and Yao, D. (2014), "Mapping supply chain strategy: an industry analysis", Journal of Manufacturing Technology Management, Vol. 25 No. 3, pp. 351-370. 
Naylor, B., Naim, M. and Berry, D. (1999), "Leagility: integrating the lean and agile manufacturing paradigms in the total supply chain", International Journal of Production Economics, Vol. 62 Nos 1/2, pp. 107-118.

Okoli, C. and Pawlowski, S. (2004), "The Delphi method as a research tool: an example, design considerations and applications", Information and Management, Vol. 42 No. 1, pp. 15-29.

Olhager, J. (2003), "Strategic positioning of the order penetration point", International Journal of Production Economics, Vol. 85 No. 3, pp. 319-329.

Pagh, J. and Cooper, M. (1998), "Supply chain postponement and speculation strategies: how to choose the right strategy", Journal of Business Logistics, Vol. 19 No. 2, pp. 13-33.

Perez-Franco, R., Phadnis, S., Caplice, C. and Sheffi, Y. (2016), "Rethinking supply chain strategy as a conceptual system", International Journal of Production Economics, Vol. 182, pp. 384-396.

Purvis, L., Spall, S., Naim, M. and Spiegler, V. (2016), "Developing a resilient supply chain strategy during 'boom' and 'bust”, Production Planning and Control, Vol. 27 Nos 7/8, pp. 579-590.

Qi, Y., Huo, B., Wang, Z. and Yeung, H. (2017), "The impact of operations and supply chain strategies on integration and performance", International Journal of Production Economics, Vol. 185, pp. 162-174.

Qi, Y., Zhao, X. and Sheu, C. (2011), "The impact of competitive strategy and supply chain strategy on business performance: the role of environmental uncertainty", Decision Sciences, Vol. 42 No. 2, pp. 371-389.

Randall, T., Morgan, R. and Morton, A. (2003), "Efficient versus responsive supply chain choice: an empirical examination of influential factors", Journal of Product Innovation Management, Vol. 20 No. 6, pp. 430-443.

Roh, J., Hong, P. and Min, H. (2014), "Implementation of a responsive supply chain strategy in global complexity: the case of manufacturing firms", International Journal of Production Economics, Vol. 147, pp. 198-210.

Sackman, H. (1974), Delphi Assessment: expert Opinion, Forecasting and Group Process, Rand, Santa Monica, CA.

Schnetzler, M., Sennheiser, A. and Schönsleben, P. (2007), “A decomposition-based approach for the development of a supply chain strategy", International Journal of Production Economics, Vol. 105 No. 1, pp. 21-42.

Selldin, E. and Olhager, J. (2007), "Linking products with supply chains: testing fisher's model”, Supply Chain Management: An International Journal, Vol. 12 No. 1, pp. 42-51.

Sharma, P. and Kulkarni, M. (2016), "Bayesian belief network for assessing impact of factors on army's lean-agile replenishment system”, Journal of Military Studies, Vol. 7 No. 1, pp. 11-23.

Sharman, G. (1984), "The rediscovery of logistics", Harvard Business Review, Vol. 62 No. 5, pp. 71-80.

SIPRI (2019), "SIPRI yearbook 2019”, available at: www.sipri.org/yearbook/2019/04 (accessed 11 June 2020).

Skulmoski, G., T. Hartman, F. and Krahn, J. (2007), "The Delphi method for graduate research”, Journal of Information Technology Education: Research, Vol. 6, pp. 001-021.

Swartz, S. and Johnson, A. (2004), "A multimethod approach to the combat air forces mix and deployment problem”, Mathematical and Computer Modelling, Vol. 39 Nos 6/8, pp. 773-797.

The Swedish MoD (2015), "Sweden's defence policy 2016 to 2020", available at: www.government.se/ globalassets/government/dokument/forsvarsdepartementet/sweden_defence_policy_2016_to_ 2020 (accessed 11 June 2020).

von Falkenhausen, C., Fleischmann, M. and Bode, C. (2019), "How to find the right supply chain strategy? An analysis of contingency variables", Decision Sciences, Vol. 50 No. 4, pp. 726-755.

Vonderembse, M., Uppal, M., Huang, S. and Dismukes, J. (2006), "Designing supply chains: towards theory development", International Journal of Production Economics, Vol. 100 No. 2, pp. 223-238. 
JDAL

4,2

Wilhite, A., Burns, L., Patnayakuni, R. and Tseng, F. (2013), "Military supply chains and closed-loop systems: resource allocation and incentives in supply sourcing and supply chain design", International Journal of Production Research, Vol. 52 No. 7, pp. 1926-1939.

Worrell, J., Di Gangi, P. and Bush, A. (2013), "Exploring the use of the Delphi method in accounting information systems research", International Journal of Accounting Information Systems, Vol. 14 No. 3, pp. 193-208.

Yang, B. and Burns, N. (2003), "Implications of postponement for the supply chain", International Journal of Production Research, Vol. 41 No. 9, pp. 2075-2090.

Yang, B., Burns, N. and Backhouse, C. (2004), "Postponement: a review and an integrated framework", International Journal of Operations and Production Management, Vol. 24 No. 5, pp. 468-487.

Yoho, K., Rietjens, S. and Tatham, P. (2013), "Defence logistics: an important research field in need of researchers", International Journal of Physical Distribution and Logistics Management, Vol. 43 No. 2, pp. 80-96.

\section{Corresponding author}

Thomas Ekström can be contacted at: thomas.ekstrom@fhs.se

For instructions on how to order reprints of this article, please visit our website: www.emeraldgrouppublishing.com/licensing/reprints.htm

Or contact us for further details: permissions@emeraldinsight.com 